\title{
Child Pornography
}

Alisdair A. Gillespie.*

It would seem, at one level, to be somewhat gratuitous to include an article on child pornography in a special issue on 'Dangerous Speech'. Child pornography would seem to obviously meet the criteria of dangerous speech, with no real discussion required. However, as will be seen in this article, this is not necessarily the case. There remain a number of controversial issues that potentially raise both under-criminalisation and over-criminalisation.

This article seeks to critique the current law of child pornography using doctrinal methods, to assess its impact and reach. It will do this by breaking down the definition of child pornography into its constituent parts, identifying how the law has constructed these elements and whether they contribute to an effective legislative response to tackling the sexual exploitation of children through sexual images. The article concludes that there are some areas that require adjustment and puts forward the case for limited legislative changes to ensure that exploitative pictures are criminalised but in such a way that innocent pictures are not.

\section{DEFINING CHILD PORNOGRAPHY}

There is no single definition of 'child pornography' and indeed the term itself remains controversial. ${ }^{1}$ In order to understand the interaction between child pornography and dangerous speech, it is necessary to consider the definition of child pornography. The difficulty with this is that there are hundreds of different definitions available. Even international law cannot agree, with different definitions being used in the Optional Protocol to the CRC on the sale of cbildren, child prostitution and child pornography' (hereafter 'OPSC') and the Council of Europe Convention on the Protection of Children against Sexual Exploitation and Sexual Abuse' (hereafter 'Lanzarote Convention'4). Domestically, there is no such thing as 'child pornography' in English law, but instead a series of offences come together to cover material considered 'child pornography'.

Even if one could settle on an agreed definition, there is an argument that any definition will underplay the significance of what child pornography, or rather some forms of child pornography, is. Indeed it has been suggested that, '[w]hile definitions are helpful and informative, they fail to adequately convey the content of child pornography'. ${ }^{6}$ The idea behind such statements is that it is only when one has seen the images that one can truly understand what child pornography is; that it is not erotica but, as Edwards has suggested, it is the 'representation of the rape, abuse and torture of children'. ${ }^{7}$ To others, however, such emotion is problematic. They argue that the increasingly intolerant approach that is taken to depictions of childhood sexuality, actually overtly sexualises children, meaning that the law does the very

Professor of Criminal Law and Justice, Lancaster University.

1 Law enforcement and child protection charities have, for some time, objected to the term 'child pornography' arguing that it downplays the significance of what is happening. The Interagency Woking Group on Sexual Exploitation of Children has produced some guidance ('Luxembourg Guidelines') which seeks to move people towards using 'child sexual abuse material'.

A/RES/54/263 of 25 May 2000.

CATS No 201.

Conventions are invariably named after where they are signed, particularly when their formal names are long. Most notably those under s.1, Protection of Children Act 1989 and s.62, Coroners and Justice Act 2009.

Esposito, L.C. 'Regulating the Internet: The New Battle Against Child Pornography' (1998) 30 Case Western Reserve Journal of International Law 541-565 at 543.

7 Edwards, S.S.M. 'Prosecuting 'child pornography': possession and taking of indecent photographs of children' (2000) 22 Journal of Social Welfare and Family Law 1-21 at 1. 
opposite of what it is trying to do. ${ }^{8}$ This is something that will be discussed further below when considering how the laws now operate.

Regardless of the precise definition, there are three key elements to any definition:

1. Child. What constitutes 'a child' for the purposes of child pornography?

2. Material. What forms of material are to be included within any definition of child pornography?

3. Nature of the material. What is it about the material that makes it child pornography, i.e. what is 'pornographic' about it (if this is indeed the test).

Each of these raise considerable issues when considering the notion of dangerous speech and the efficacy of any child pornography offence.

\section{Child}

The first issue to consider is what constitutes 'a child'. There are two dimensions to this argument. The first is what age a person should be for them to constitute a 'child' for the purposes of child pornography. The second is whether a real child must be used in the production of child pornography. This is a particularly controversial part of the debate about potential overreach in child pornography laws but as other elements also raise the same issue, it will be discussed elsewhere.

This leaves age. What should the age of a 'child' be for the purposes of child pornography? Defining 'childhood' is notoriously difficult. There is no general consensus in either science or the social sciences about what a child is. Traditionally, one of the more common ways of demarcating 'child' from 'adult' was when a child went through puberty. However, puberty would be singularly unhelpful for the purposes of legally defining a child. For a start, puberty is a transition and not a single moment in time, so does one use the start or finish of puberty? Second, whilst the menarche marks a physical point which is obvious for a female, there is no male equivalent. Thus, how does one decide at what point a boy has reached puberty? Third, even the menarche would be singularly unhelpful in terms of child pornography, since menstruation is not something that is likely to be photographed in the context of child pornography so there would be no obvious way of determining this without identifying the child. Finally, puberty is something that happens to children at different stages of their lives, and is commonly thought to take place between the ages of 10 and 13 for girls. ${ }^{9}$ However, a number of factors can influence the age at which a girl enters puberty, including genetics, race and body mass index. ${ }^{10}$

If there is not any physical way of determining when a person ceases to be 'a child', then realistically we are left with setting an age for 'a child'. What age should this be? In England \& Wales, when the Protection of Children Act 1978 was first introduced, the age chosen was 16 which was the same as the age of (sexual) consent. There was logic in such an approach. When first

8 See, for example, Danay, R.J. 'The Danger of Fighting Monsters: Addressing the Hidden Harms of Child Pornography Law' (2005) 11 Review of Constitutional Studies 151-191 at 153.

9 Parent, AS et al 'The Timing of Normal Puberty and the Age Limits of Sexual Precocity: Variations around the World, Secular Trends, and Changes after Migration' (2003) 24 Endocrine Reviews 668-693 at 670-671.

10 See, for example, Kaplowitz, PB et al 'Earlier Onset of Pubert in Girls: Relation to Increased Body Mass Index and Race' (2001) 108 Pediatrics 347-353. 
introduced, the photographs generally captured the picture of a crime. Where a photograph depicts a child under the age of 16 engaging in sexual activity this is recording illegal activity. ${ }^{11}$

In 2004 the age of 'a child' was raised in England \& Wales to $18 .^{12}$ This followed pressure from children's charities but was also arguably a requirement of international law. ${ }^{13}$ The increase to the age of 18 received very little public comment and yet it alters the justification for the offence. As noted in the preceding paragraph, photographing a sexual act involving a child under 16 can be seen as documenting a crime. The same cannot be said of photographing a 16 or 17 -year old. A 16 or 17-year-old can choose to have sexual activity, including sexual intercourse. Therefore, the photograph no longer depicts a crime, indeed it actually depicts a lawful act. The law thus creates a situation where a photograph is considered more serious than actual sexual activity. D, aged 18, is guilty of an offence punishable by up to ten years' imprisonment if he photographs his 17year-old girlfriend topless, ${ }^{14}$ yet if he has sexual intercourse with the same 17 -year-old there is no liability.

Why was the age raised? The principal concern appears to be the permanency of the image. There is clear evidence to suggest that once a sexualised image is placed onto the internet then it is virtually impossible for it to be removed. ${ }^{15} \mathrm{~A}$ decision that seems sensible as a carefree 16-yearold may not seem as appropriate 20 years' later when being interviewed for a senior post or standing for political office. ${ }^{16}$ There must also be the risk that a teenager is more at risk of exploitative situations. Thus, they may be more readily tricked into giving consent / acquiescence to the taking of photographs than a person who is older. That said, the counter-argument is that there is certainly no guarantee that age leads to wisdom. It is far from certain that an 18-year-old is in any better position to judge the appropriateness of allowing themselves to be photographed than a 16-year-old is.

Jenkins is dismissive of the global trend to move towards an age of 18:

Seventeen-year-olds are not children, and it is ludicrous to try to impose upon them the same limitations that apply to seven-year-olds... we cannot carry on pretending that sexuality is a mysterious force that descends on a person suddenly on his or her eighteenth birthday, prior to which the individual remains in pristine innocence. ${ }^{17}$

This perhaps goes to the heart of what the offence is for. Whilst there is undoubtedly a risk that a 16-year-old could be exploited, the same is true of those who engage in sexual activity. Yet, in England \& Wales, we set the age of consent at 16 and only have limited exceptions that require a

11 See, sections 9 and 10, Sexual Offences Act 2003. This applies even where the photograph depicts solo activity so long as it is directed by an adult.

12 See s.45, Sexual Offences Act 2003.

13 The OPSC applying to children under the age of 18, the Lanzarote Convention doing likewise but perhaps, most significantly, the (binding) EU Council Framework Decision 2004/68/JHA on combating the sexual exploitation of children and child pornography defined a child as being under 18.

14 Section 1(1)(a), Protection of Children Act 1978.

15 Taylor, M. and Quayle, E. Child Pornography: An Internet Crime (2003, Hove: Routledge) p.24.

16 An interesting example of the latter is Gloria del Piero, the Labour MP for Ashfield. In 2010 it was reported that topless photographs of her had been taken when she was 15 , whilst attempting to start a modelling career. It is unlikely that at 15 she thought of a political career or the consequences of these photographs. The case is also interesting because those images would have been illegal when they were taken since that would have been c.1987, when taking an indecent photographs of a child under 16 was an offence.

17 Jenkins, P. Beyond Tolerance: Child Pornography on the Internet (2001, New York: New York University Press) at 220. 
higher age. ${ }^{18}$ Can it really be said that photography is any more serious than exploitative intercourse? As to whether there are permanent risks, the same can be said for sexual intercourse. Yes, photographs have a degree of permanence but so do pregnancy and sexuallytransmitted diseases. The law considers 16-year-olds perfectly able to navigate these risks (a 16year-old could legally choose to have unprotected sexual intercourse with a person H.I.V. positive or who someone who has herpes), yet it does not permit a 16-year-old to navigate the risks of photography, something that could be seen as overly paternalistic.

Perhaps the key is to return to the comment of Jenkins. What is the purpose of the legislation? It is to protect children. According to the Internet Watch Foundation, 53\% of material discovered by them was assessed as featuring a child aged 10 or under. ${ }^{19} \mathrm{~A}$ further $45 \%$ of material was considered to involve children aged between 11 and 15 although, as will be seen, a degree of scepticism must occur in respect of identifying age. This means that $98 \%$ of material involve children under the age of 16. Should it not be this that the authorities concentrate on? Why raise the age of 'a child' when we are still fighting to ensure that young children are no longer forced to participate in child pornography.

\section{Ascertaining age}

If an age is to be prescribed then an additional question that must be considered is how this age should be ascertained. With sexual assaults, it is relatively easy to identify the age of a child: the victim is asked or, if it is too young, they are identified and their date of birth ascertained from records. What happens in respect of cases of child pornography? The same is true for child pornography when the victim is known. However, few offenders are identified ${ }^{20}$ and most conduct relates not to the creation of child pornography but to its distribution or downloading (where identification is arguably more difficult). ${ }^{21}$

Where the child is not known, the prosecution must prove age in some other way. In many instances this will not be problematic. It will be remembered that the IWF report that over onehalf of child pornography they identified involved a child under the age of 10 . In such instances it will not be necessary for the prosecution to prove the age of the child since there is no requirement to identify a precise age, the single issue is whether the child is under the age of 18, and in many instances this will be self-evident.

What of older children? This is one area where the increased age could be of benefit. In many instances it may be easier to tell the difference between a 13/14 year-old and an 18-year-old than it would to tell the difference between a 13/14-year-old and a 16-year-old. That may have been a justification for raising the age of 'a child', although it is not one that was readily advanced. Of course, the belief that it is easier to identify is a generalisation and there will be many instances where it is not easy to ascertain age. Once again, it should be remembered that the prosecution need not prove the age of the child, only that the child is under the age of 18 .

In $R v$ Land $^{22}$ the Court of Appeal held that expert evidence as to age was not required, and indeed not admissible. The Court held that expert evidence is reserved for situations where it is

18 See, for example, Gillespie, A.A. and Ost, S. "The "higher" age of consent and the concept of Sexual Exploitation' in Reed, A. and Bohlander, M. The Law of Consent: Domestic, Comparative and International Perspectives (2017, Routledge) (pp.161-176).

19 Annual Report 2016 (2016, Cambridge: IWF).

20 Elliott, I.A. and Beech, A.R. 'Understanding online child pornography use: applying sexual offense theory to internet offenders' (2009) 14 Aggression and Violent Behaviour 180-193 at 181.

21 Gillespie, A.A. Child Pornography: Law and Policy (2011, Abingdon: Routledge) pp.6-7.

22 [1999] QB 65. 
necessary 'to assist the court with information which is outside the normal experience and knowledge of the judge or jury'. ${ }^{23}$ The court believed that identifying whether a person featured in a photograph was below a particular age was something that 'the jury is as well placed as an expert to assess'. ${ }^{24}$ This is certainly not the case all around the world, and in the USA, for example, it is common for paediatricians to give evidence as to the likely age of a child portrayed in a photograph. Given the consequences of a conviction for offences relating to child pornography, ${ }^{25}$ it may seem strange that expert evidence is not required, especially since the age at which children mature differs.

There does appear some evidence that lay persons are as good at identifying the age of children as experts, ${ }^{26}$ although that was one study and did not involve the use of real children as subjects. However, research suggests identifying age is complicated. ${ }^{27}$ Perhaps the rejection of expert evidence is designed, in the absence of a defence of mistaken belief, to cater for those situations where there is doubt over the age of a child. Let us take a hypothetical case involving a photograph of an adolescent female who has clearly gone through puberty. Her breasts and hipstructure are developed. She may look 15, 17 or even 19. How does a jury decide age? If expert evidence was called then a number of scientific tests would be put forward and ultimately one or more experts would state what their view is. The jury could ultimately decide not to accept the view of the expert, but it is perhaps more likely that they would choose the expert they found the most convincing. Where expert evidence is not admitted, the jury must look at the image themselves and reach a judgment. Where the defendant says, "I thought that the victim was aged over 18" this does not, in law, amount to a defence, but because the jury are looking at the image without outside assistance, they are ultimately asking whether such an argument was plausible. If they believe that the person in the image was capable of being older then they should acquit because they cannot be 'sure ${ }^{28}$ that it is of someone under the age of 18 . To that extent, perhaps the absence of expert evidence is the law's way of ensuring that the image is looked at through a lay-person's eyes and not the gaze of those who are looking for evidence of childhood.

\section{Nature of the Material}

The second issue to consider is the test for child pornography. That is to say, what is the threshold that makes something child pornography as distinct from lawful material? At an international level, there is no standard test. Most instruments operate by prescribing the description of activities or the sexual organs of a child. ${ }^{29}$ This is usually accompanied by a requirement that the display is for a sexual purpose. This test has the advantages of being certain but it is not exhaustive and allows for questions to be raised about, for example, the primary focus of the image.

In England \& Wales, the test is easier to describe but more difficult to define. The Protection of Cbildren Act 1978 refers to an 'indecent' photograph of a child. ${ }^{30}$ Thus the test is that material must be 'indecent' but what does this mean? The Act is completely silent as to what 'indecent'

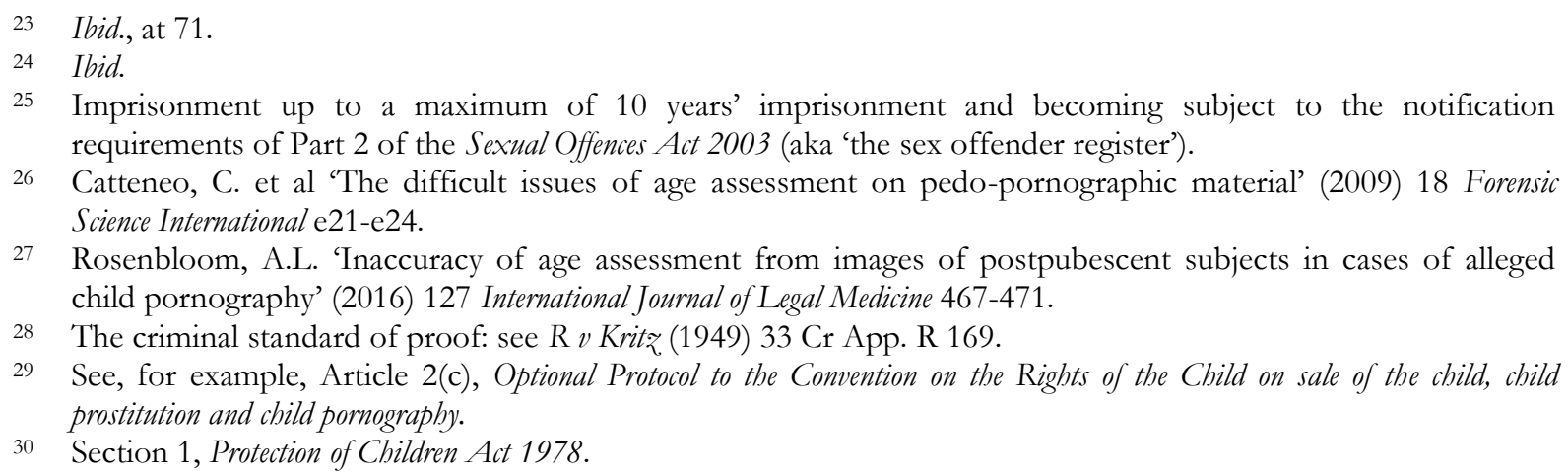

27 Rosenbloom, A.L. 'Inaccuracy of age assessment from images of postpubescent subjects in cases of alleged child pornography' (2016) 127 International Journal of Legal Medicine 467-471.

28 The criminal standard of proof: see $R v$ Kritz (1949) 33 Cr App. R 169.

29 See, for example, Article 2(c), Optional Protocol to the Convention on the Rights of the Child on sale of the child, child prostitution and child pornography.

30 Section 1, Protection of Children Act 1978. 
means. Part of the reason for this is presumably because it was thought that the term was readily understood. ${ }^{31}$ Certainly there were, at the time of its introduction, other offences that made reference to indecent material, ${ }^{32}$ with later offences being added. ${ }^{33}$ The common law provided a definition in the absence of a statutory definition.

In $R v$ Stanley $^{34}$ the Court of Criminal Appeal held that 'indecent' and 'obscene' were separate terms, but that they existed on the same scale, with 'indecent being at the lower end of the scale and obscene at the upper end of the scale. ${ }^{35}$ In the context of child pornography this makes sense. The original Protection of Children Act 1978 did not tackle the possession of child pornography, but rather its creation and distribution. At the time of the legislation there were questions over the necessity of the new legislation because it was thought that it could be covered by existing obscenity legislation. ${ }^{36}$ By choosing 'indecent' it would seem that Parliament was knowingly reducing the threshold for criminal intervention in these circumstances. Lord Parker CJ explained the difference; 'an indecent article is not necessarily obscene, whereas an obscene article almost certainly must be indecent'. ${ }^{37}$

Thus 'indecent', in this context, requires the jury to consider whether the image offends against standards of propriety. In $R v \mathrm{Owen}^{38}$ the Court of Appeal accepted that the age of the victim must be relevant to the decision. A photographer took a picture of a 14-year-old girl who wished to become a model. The pictures included shots that showed the victim scantily clad and with bare breasts. Such photographs were not uncommon for modelling at that time but the question arose whether the age of the child made them indecent? The Court held that age was relevant. The jury should not consider whether the photograph is indecent irrespective of who the subject is and, if so, then decide whether the subject is a child. Instead, the jury should consider whether the age of the child means the image is more likely to offend standards of propriety.

Other countries adopt similar tests. Under the Federal Law of the USA, the test for child pornography includes, inter alia, the lascivious exhibition of the genitals or pubic area. ${ }^{39}$ 'Lasciviousness' is not defined and so it has been left to the courts. As with 'indecent', the US courts have held that it is not the same as 'obscene' and can include material that is of a lesser standard. ${ }^{40}$ In US $v$ Dost ${ }^{41}$ the District Court suggested a number of factors (some of which have been criticised) including whether the 'visual depiction is sexually suggestive' and whether it implies a willingness of the subject to engage in sexual activity. ${ }^{42}$ In US $v$ Wiegand $^{13}$ it was held to involve the presentation of a child as a sexual object and in $U S v$ Ray $I^{14}$ as identifying a sexualised context.

31 It is notable that attempts at trying to include a definition were resisted. For example, Lord Beaumont of Whitley moved an amendment in the House of Lords to define (in negative terms) 'indecent' but this was defeated: see Hansard, HL Deb, vol 392, col 558, 18 May 1978.

32 For example, s.11, Post Office Act 1953 (indecent or obscene articles through the post).

33 See, for example, s.43, Telecommunications Act 1984 (grossly offensive, indecent, obscene or menacing phone calls) (now replaced by s.127, Communications Act 2003).

34 [1965] 2 QB 327.

35 Ibid. at 333 per Lord Parker CJ.

36 See, for example, M. McCarthy and R.A. Moodie 'Parliament and Pornography: The 1978 Child Protection Act' (1981) 34 Parliamentary Affairs 47-62 at 52.

7 [1965] 2 QB 327 at 334.

38 [1988] 1 WLR 134.

3918 USC $\$ 2256(8)$ when read in conjunction with 18 USC $\$ 2256(2)(B)$.

40 US v Arvin 900 F.2d 1385 (9th Cir, 1990).

$41 \quad 636$ F.Supp. 828 (S.D.Cal, 1986).

42 Ibid., at 832.

43812 F.2d. 1239 (9th Cir, 1987).

$44 \quad 270$ F.3d. 709 ( $8^{\text {th }}$ Cir, 2001). 
Tests such as those used in England \& Wales and the USA have been criticised for sexualising children, something that the legislation was intended to prevent. It has been noted that an objective test for child pornography requires 'us to take on the gaze of the paedophile to root out pictures of children that harbour secret pedophillic [SIC] appeal'. ${ }^{45}$ This is an unappealing thought. That in order to decide whether material is illegal we become the paedophile. We dress it up by suggesting that we are looking at what a paedophile would find of interest, but in essence it means that we are having to approach the matter from the mind of a paedophile. The difficulty with such an approach is that it means that we sexualise images that would otherwise not be sexualised. So, for example, in the United Kingdom there are at least two famous instances where the law has taken on the gaze of the paedophile. The first is an old case in respect of the then newsreader Julia Somerville. She and her partner were arrested for suspected child pornography offences because they had taken pictures of their six-year old daughter in the bath. This must be a classic example of Adler's point. A parent taking a photograph of their child in the bath is unlikely, in most instances, to be sexualised. A photograph of a child in the bath is only sexual because we fear that it can be used as a sexual photograph. We fear that the paedophile will look at such pictures and gain sexual gratification from them.

The same is true of the second notable example. This concerned a photograph by Nan Golding, an American artist. One photograph entitled 'Klara and Edda Belly-Dancing' was being exhibited at an art gallery when it was seized by the police as being potentially indecent. The picture shows two children, who have the appearance of being under the age of 10 . The first is partially naked and the second is lying on the floor completely naked, with her vaginal area displayed. The image had previously been exhibited all over the world and was considered to be influential art. There was nothing inherently sexual in the image, although the genital area of at least one child was displayed and presumably this is why it was subject to the investigation. However, it would seem to be another classic example of Adler's point. It was under investigation because there was a belief that the picture could be of interest to paedophiles.

The difficulty with both examples was the definition of 'indecent'. The test, as has been seen, simply requires a decision on whether they offend recognised standards of propriety and the photographs potentially meet this threshold. Yet this ignores the context. In respect of the Nan Golding image, the fact that it was a legitimate artistic enterprise was missed. In the Julia Sommerville case, it was even worse. One of the leading family lawyers at the time, suggested that by taking photographs of her children she was 'playing with fire'. ${ }^{46}$ Why? In many households, bath time is a time of fun and it is easy to see why someone may wish to capture those moments in a photograph. Why was it unwise and deserving of a police investigation? The only possible way that the image could be construed in this way, is if the photograph was viewed through the gaze of the paedophile.

What is the alternative? The most obvious solution would be to move away from the gaze of the paedophile, but how? Realistically a wholly subjective test would not be appropriate. This would require the law to consider whether the individual was using the material in a sexuallyinappropriate way. However, the breadth of material that offenders use for sexual gratification could lead to absurd results. For example, it is known that some offenders use pictures of children in underwear or swimsuits as stimuli for sexual gratification. ${ }^{47}$ Could we realistically say that this amounted to child pornography? It would seem absurd. In fact, at least one decision of

45 Adler, A. 'The perverse law of child pornography' (2001) 101 Columbia Law Review 209-273 at 213.

46 'Julia Somerville defends innocent family photos' (1995) The Independent, 5 November, News.

47 Taylor, M.; Holland, G. and Quayle, E. 'Typology of Paedophile Picture Collections' (2001) 74 The Police Journal 97-107 at 100 . 
the Federal courts in the USA reached this decision. In US v Knox $x^{48}$ the Third Circuit Court of Appeals held that footage that showed a child clothed in swimwear dancing in a sexually provocative way could constitute child pornography. The decision has been criticised $^{49}$ and it does seem difficult to reconcile with the essential aims of child pornography laws. The essential harms that child pornography laws are seeking to address are to prevent children being abused in the production of child pornography or exploited through its use. It would be difficult to suggest that the fudge in Knox infringes either of these harms. There must be a danger that including too broad a range of material in any definition of child pornography will undermine the public's confidence in the law. For example, if photographs from underwear catalogues etc. or swimming galas are brought within the definition then people are likely to believe that the laws are overbroad.

Another difficulty with a purely subjective test is whose motivation should be relevant. Should it be the photographer, the distributor or the possessor? This is actually a more profound question than it may seem. Let us take an example:

A, a father, takes a picture of his 18-month old daughter in the bath. It is an innocuous, family photograph although it features the child naked.

B breaks into A's house and steals, amongst other things, A's tablet and mobile telephone. When looking through the footage he sees the image of A's daughter in the bath. He realises that this photograph could be sold to people online. He contacts C, who operates a child pornography website, who buys it from B and then hosts it on the site.

D downloads the image from the internet and uses it to masturbate to.

If a subjective test is to be adopted, whose motivation is considered? If it is the person who takes the photograph (A) then this would create a problem as the photograph would presumably be considered lawful, meaning that $\mathrm{B}, \mathrm{C}$ and $\mathrm{D}$ could not be prosecuted. If the subjective test required a person to have a sexual motivation then $\mathrm{B}$ and $\mathrm{C}$ would not be culpable, although presumably one way around this would be to require the sexual motivation to be for themselves or for another. In England \& Wales, the offence of voyeurism is an example of this approach whereby it captures behaviour for the sexual gratification of oneself or another. ${ }^{50}$ However, by itself this would not resolve the issue that a purely subjective test would lead to a situation where innocuous material could fall within a definition of child pornography purely because of the motivations of the offender, potentially over-broadening the definition.

Child pornography is not the only area that has grappled with these issues. The old law of indecent assault was an assault that was indecent. ${ }^{51}$ This meant that the concept of 'indecent' needed to be defined for these purposes. As with the position in respect of indecent photographs, the Sexual Offences Act 1956 did not define 'indecent' and thus it was left to courts. The leading case on this was $\mathrm{R} v$ Court $^{2}$ which concerned a shop assistant who hit a 12 -year-old girl on the buttocks over her shorts. The complainant did not consider there to be any motivation but the defendant, when questioned, admitted to there being a sexual motivation, in that he had a fetish for buttocks. The question arose whether this was an indecent assault.

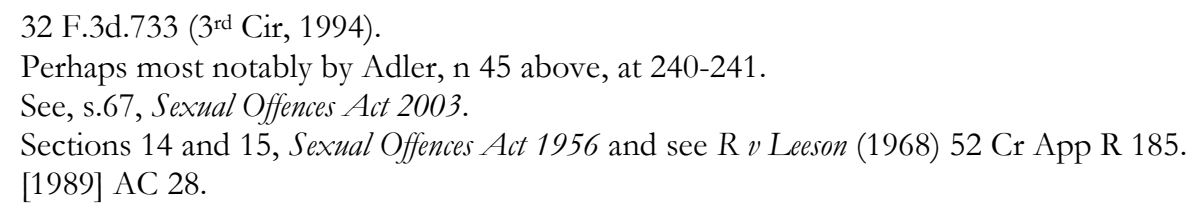


The House of Lords held that a purely objective or purely subjective test would be inappropriate. They relied on an earlier decision, where it was held that a person who removed a shoe from a woman could not be convicted of indecent assault because he secretly had a foot fetish. ${ }^{53}$ The House was clear that there had to be some objective element that would justify a conclusion that there was indecency. However, the House also believed that a purely objective test would not be appropriate either and that the court should take account of the 'circumstances in which the assault took place'. ${ }^{54}$ The House believed that the motivation of the offender could be a circumstance of the assault. Whilst, therefore, an indecent motivation could not turn an innocuous assault into an indecent assault, it could allow a jury to infer that an assault that is capable of being an indecent assault was, in fact, indecent because of the motivation of the offender.

Out of this case grew the Court test for indecency which then formed the basis for the statutory definition of 'sexual' under the Sexual Offences Act $2003 .^{55}$ This definition holds that an act is sexual if:

(a) whatever its circumstances, or any person's purpose in relation to it, it is because of its nature sexual, or

(b) because of its nature it may be sexual and because of its circumstances or the purpose of any person in relation to it (or both) it is sexual.

This is an interesting test that could perhaps be taken forward for child pornography to define 'indecent'. The first element is objective. If right-thinking members of society would consider the act to be indecent then it is indecent irrespective of what the person's intention was. This could, for example, include the penetration of the vagina. This would be considered inherently indecent irrespective of what the actual motivation of the offender was (including, for example, a desire to humiliate or cause pain). However, it accepts that a purely objective test may mean that some matters are missed. Thus the more subjective element is that if an act is objectively capable of being indecent, but may not be, then it can become indecent because of the motivation of the offender. Court is a good example of this. Spanking on the outside of clothing is not inherently indecent. However, spanking is certainly capable of being indecent and thus the fact that it was undertaken for a sexual motivation is a circumstance that should be taken into account in deciding whether it was, in fact, indecent. However, alongside this is the point made in George that an act not capable of being indecent, cannot become indecent just because of its motivation.

It is submitted that this nuance should be adopted for use in the laws of child pornography. There are some types of photographs that cannot be considered indecent. Perhaps the classic example of this would be photographs of people in swimming costumes or clothing catalogues. Similarly there will be some photographs that are obviously indecent. A good example of this would be a photograph that shows sexual activity with a minor. There will then be cases that are capable of being indecent but may not, in fact, be. It is perhaps questionable whether the family photograph of a child in a bath would fall into this category as these are probably innocuous and a better example may be the Nan Golding photograph. Other examples may include children being photographed nude on a beach. Under these circumstances, the motivation of the suspect would be examined. The photograph would only be indecent/sexual if it is being used for an indecent purpose, eg downloading for sexual gratification.

53 See R $v$ George [1956] Crim LR 52.

54 [1989] AC 28 at 43 per Lord Ackner.

55 See s.78, Sexual Offences Act 2003. 
Does this resolve the criticism of Adler and others that the law adopts the paedophile gaze? Probably. There is still the argument that the gaze is required because we are judging whether an image is capable of being indecent: i.e. we are on the prowl that an image might be of interest to a sex offender. However, by then taking the motivation of the offender into account, the gaze is arguably averted whereas currently the fact that it is capable of being indecent means it is treated as indecent, thus criminalising material that should not be criminal. To that extent, the s.78/Court test would be a welcome development.

\section{Type of Material}

The third element of the definition is the type of material. The definition put forward in the OPSC is interesting because it makes reference to representation 'by whatever means' ${ }^{56}$ This is a broad provision that must include all forms of child pornography, but few contries go this far, with the majority restricting themselves to visual depictions. ${ }^{57}$ The same is true of most international instruments other than the OPSC. ${ }^{58}$

What sort of material could be included? There are four broad categories of material:

1. Photographs (or derivatives of photographs).

2. Drawings (including computer generated images).

3. Text.

4. Sound.

The legislation relating to indecent photographs of children covers only the first category. A separate piece of legislation now covers the second category of material, ${ }^{59}$ and this covers not only virtual child-pornography but also material such as drawings.

Text is not criminalised under either piece of legislation. When the Protection of Cbildren Act 1978 proceeded through Parliament there was an attempt to include text-based forms of material into the legislation but this was rejected. ${ }^{60}$ Some countries do seek to cover text-based child pornography, most notably Ireland and Canada. Drafting a law that is not over-broad and infringes freedom of expression is challenging for text. How does a law adequately cover stories that seek to glorify child sexual abuse without also criminalising literary works such as Nabokov's Lolita? One approach is to include defences relating to artistic merit, ${ }^{61}$ but this invariably causes difficulties for the courts, with experts disagreeing and the issue of 'merit' being fiercely contested. The courts should not be placed in the position whereby they become literary critics, deciding on whether art is any good. ${ }^{62}$ As text does not visually depict the actual abuse of a real child, its possession raises issues of freedom of expression, something traditionally guarded by liberal democracies. The Supreme Court of Canada held that privately-held text materials that were created by the possessor and were not disseminated to anyone could not be criminalised because to do so infringed the creator's rights. ${ }^{63}$ Whilst the European Court of Human Rights has traditionally adopted a more conservative approach to obscenity, ${ }^{64}$ this was in the context of

56 Article 2(c), Optional Protocol to the Convention on the Rights of the Child on the sale of children, child pornography and child prostitution.

57 See Gillespie, A.A. 'Defining child pornography: challenges for the law' (2010) 22 Child and Family Law Quarterly 200-222 at 214.

58 Ibid., at 219.

59 Section 62, Coroners and Justice Act 2009.

60 McCarthy and Moodie, n 36 above, at 57,

61 See, for example, the position in Canada at s.163.1(6),(7), Criminal Code.

62 See the caution expressed by McLachlin CJ in R $v$ Sharpe 2001 SCC 2 at [64] et seq.

63 Ibid., at [76].

64 See, for example, Handyside v UK (1979) 1 EHRR 737 and Müller v Swtizerland (1991) 13 EHRR 212. 
public displays and it is quite possible that private possession would be dealt with differently, more in line with the Canadian approach. This demonstrates the difficulty of text and why the law in England \& Wales has perhaps steered clear of this. ${ }^{65}$

\section{Photographs}

Photographs are perhaps the easiest type of material to discuss. If, as many would suggest, photograph-based child pornography is the visual depiction of a child being sexually assaulted, then criminalising photographs is readily justified under the harm principle. The photograph requires a child to be abused and therefore it directly contributes to the harm a child suffers. It is for this reason that photographic child pornography is sometimes referred to as being the picture of a crime scene. ${ }^{66}$ Whilst this may be true, does this necessarily justify criminalisation? Photographing the scene of a crime is not normally a criminal offence. One could photograph the scene of a murder without attracting criminal liability. So by itself, this cannot justify criminalising photography and it is better to rely on harm.

The harm justification can be taken further because not only is there the harm the child suffers in its production (ie the abuse), but there is clear evidence that additional psychological harm is caused by being filmed whilst abused. ${ }^{67}$ This has received judicial comment/approval where it was noted that photographs mean that there is a long-term effect on the child, with psychological harm being caused by the knowledge that people out there [were] getting a perverted thrill from watching them forced to pose and behave in this way' ${ }^{68}$

What of the situation where there is no abuse? It was noted in the previous section that images can be considered indecent even if they do not show any sexual activity. This could include situations where people ask children to pose sexually or where footage has been gathered through covert means. It was noted earlier that criminalising such footage can also be justified because it is exploitative. The photograph shows the child in a way that sexualises him or her and the secondary impact identified in Beaney may also apply to a child portrayed in such a photograph. Even if it is not showing sexual activity, it is likely that a child who is depicted in an indecent way could suffer the same consequences if they knew that an indecent photograph of themselves was being circulated, with people using it to obtain sexual gratification. ${ }^{69}$

An alternative argument that could be advanced concerns dignity. It has been suggested that dignity is a fundamental right of the individual. ${ }^{70}$ The argument is premised on the basis that certain things are so private or personal that they relate to our individual autonomy, and that abuse of these elements constitutes an exploitation of the individual. Rogers refers to the special rules that exist in respect of Prisoners of War and the scandal of Abu Ghraib, where US service personnel abused Iraqi prisoners detained by them. ${ }^{71}$ The individual's vulnerability means that

65 Although it should be noted that dissemination of text-based child pornography is probably culpable under either the Obscene Publications Act 1959 (although this is subject to a 'public good' defence that is based, inter alia, on literary merit) or under s.127, Communications Act 2003. Neither offence is, strictly speaking, an offence relating to child pornography although it can be used for these purposes.

66 See, for example, L.C. Esposito 'Regulating the Internet: The New Battle Against Child Pornography' (1998) 30 Case Western Reserve Journal of International Law 541-565 at 544.

67 Quayle, E et al Only Pictures? Therapeutic Work with Internet Sex Offenders 2006, Russell House Publishing: Lyme Regis) at p.48.

68 R v Beaney [2004] EWCA Crim 449 at [8].

69 Taylor, M. and Quayle, E., n 15 above, at 24.

70 Rogers, A. 'The Dignitary Harm of Child Pornography - From Producers to Possessors' in Hessck, CB (ed) Refining Child Pornography Law: Crime, Language and Social Consequences (2016, University of Michigan Press) pp.165186 at 177.

$71 \quad$ Ibid. 
photographing them in that context undermines their dignity; their individual right to be treated as human and in control of their person. This breach of dignity is quite separate from the degradation they suffered in the actual abuse. The presentation of them in that context was a harm in its own right.

The concept of dignity has been applied to child pornography. In US $v$ Knox ${ }^{72}$ the Third Circuit needed to consider whether scantily-clad children dancing in a sexually-provocative way constituted child pornography. The ultimate decision was controversial ${ }^{73}$ but if that is set aside, some of the comments remain of interest. Perhaps the most pertinent is '[child pornography] is an affront to the dignity and privacy of the child and the exploitation of the child's vulnerability' ${ }^{74}$ This confirms the applicability of dignity to child pornography, and that photographing a child in such an intimate way undermines their autonomy. In Knox there was no direct sexual abuse although the facts do leave open the possibility that the children were exploited in the production. ${ }^{75}$ However, the absence of abuse did not undermine the right to dignity. It was the way that the child was portrayed that undermined dignity and autonomy and thus, in the court's view, acted as a harm against the child.

Within the European context, such a right could be encapsulated in Article 8 of the European Convention on Human Rights (ECHR). It is clear that Article 8 has both positive and negative obligations, with the European Court of Human Rights (ECtHR) having previously ruled that there is a right to bodily and psychological integrity. ${ }^{76}$ The ECtHR held that protecting the integrity of an individual was so serious, that only the exercise of the criminal law would suffice. The ECtHR has also held that Article 8 encompasses the right to a sexual identity ${ }^{77}$ and this forms part of the concept of the 'private life' of an individual. Given that Article 8 already recognises the right to shield one's identity from the public sphere where an activity is private, ${ }^{78}$ it would not be too big a step to suggest that the ECtHR would mirror the US Court of Appeals in holding that the dignity of a person is a right that requires protection.

There can be little doubt that the right to dignity would justify the criminalisation of indecent photographs of children. Even if the image does not depict sexual abuse, for it to be indecent (under English law) it will undoubtedly feature the child either naked or displaying their breasts or genitalia. It is submitted that the ability to choose who sees one's sexual organs is an inherent part of the dignity or sexual autonomy of an individual. Infringing this can legitimately be considered a matter that requires the protection of criminal law, and it is notable that laws have been enacted to uphold this autonomy for adults. ${ }^{79}$

\section{Pseudo-photographs}

Whilst photographs clearly need to be within any definition of child pornography, what is the position in respect of the derivatives of photographs? In England \& Wales these are known as a 'pseudo-photograph' and are included within the legislation. They are defined as follows:

32 F.3d. 733 (3 $3^{\text {rd }}$ Cir. 1994).

$73 \mathrm{n} 48$ above and associated main body text.

7432 F.3d. 733 ( $3^{\text {rd }}$ Cir 1994) at 750 per Cowen CJ.

75 See 32 F.3d. 733 ( $3^{\text {rd }}$ Cir, 1994) at 737 . The children were directed to pose in provocatively and dance in a fashion not natural for their age'.

$76 \quad X$ and $Y v$ Netherlands (1985) 8 EHRR 235.

77 Dudgeon v United Kingdom (1981) 4 EHRR 149; SL v Austria (2003) 37 EHRR 39.

78 See, for example, von Hannover $v$ Germany (2005) 40 EHRR 1; Peck v UK (2003) 36 EHRR 41.

79 Voyeurism (s.67, Sexual Offences Act 2003) and the so-called 'revenge pornography' laws (s.33, Criminal Justice and Courts Act 2015) can only be considered a legislative attempt to uphold the autonomy of an individual by criminalising the non-consensual acquisition or disclosure of intimate photographs. 
"pseudo-photograph" means any image, whether made by computer-graphics or otherwise howsoever, which appears to be a photograph. ${ }^{80}$

The pseudo-photograph must be distinguished from so-called 'virtual child pornography', although it is conceded that it is not always easy to do so. Perhaps the key part of the definition of a pseudo-photograph is that it must 'appear to be a photograph'. The somewhat unusual case of Goodland v DPP ${ }^{81}$ is helpful in this regard. The case concerned what was described as a 'pitiful' image that was two photographs that were spliced together with selotape to make a crude hinge. The first photograph was a pornographic image of an adult female and the second was the head of a young child. When the hinge was closed the head would appear over the picture of the adult female and appear (in a very basic way) as though it were the child who was naked. The Divisional Court quashed the defendant's conviction for possessing an indecent photograph of a child $^{82}$ saying that they patently did not have the appearance of a photograph since they were clearly two photographs. The Court held open the question whether, if they had been photographed whilst in the hinged state, they would then constitute a pseudo-photograph. ${ }^{83}$ If the image was as crude as described, then it would seem the logical response would be 'no' since it would still not appear to be $a$ photograph.

Most computer-generated images will not constitute a pseudo-photograph because they do not 'appear' to be a photograph. Instead, they appear to be a visual depiction. They lack the sufficient clarity as to imply a photograph and are instead a drawing or other visual depiction. This is perhaps more so with the advent of the 'prohibited image of a child', ${ }^{84}$ but which expressly excludes those images that are considered to be a pseudo-photograph. ${ }^{85}$ That said, some computer-generated images may have sufficient clarity that they would have the appearance of a photograph. In 0000, a children's charity developed 'Sweetie' ${ }^{86}$ This was a digital representation of an Asian child. The image was purely computer-generated but was of exceptionally high quality. A person would have to look relatively closely to identify whether Sweetie was a real photograph or a computer-generated image. It is submitted that Sweetie could have constituted a pseudo-photograph because it had the appearance of a photograph. Note, it is not that it is a photograph and thus expert evidence that it is, in fact, a computer-generated image would not assist because it is all about whether it looks as though it is a photograph. Many virtual images will not meet this standard but could not fall under the legislation on prohibited images of children (discussed below).

Section 7(8) of the Protection of Children Act 1978 demonstrates a potential use for pseudophotographs:

If the impression conveyed by a pseudo-photograph is that the person shown is a child, the pseudo-photograph shall be treated for all purposes of this Act as showing a child and so shall a pseudo-photograph where the predominant impression conveyed is that the person shown is a child notwithstanding that some of the physical characteristics shown are those of an adult.

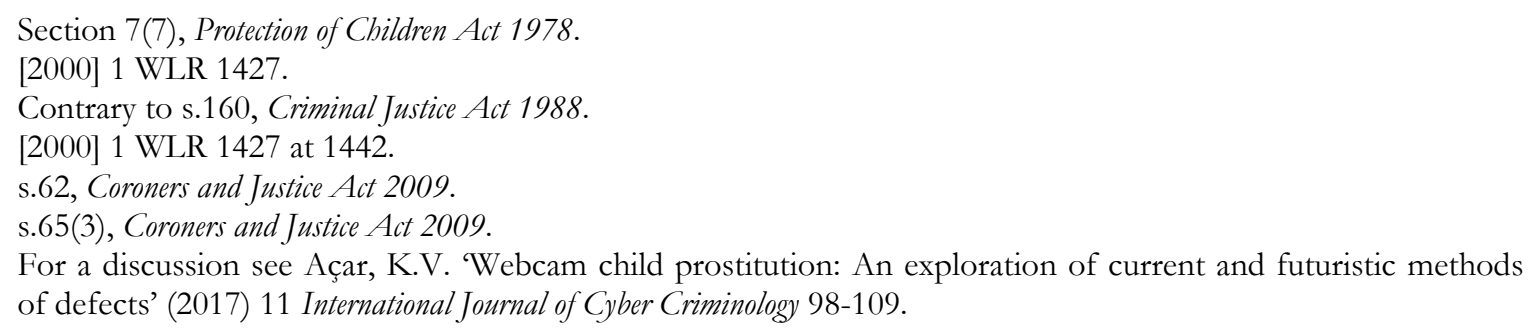


This demonstrates that pseudo-photographs are perhaps best thought of as manipulated photographs. Thus in $\mathrm{R} v \mathrm{H}^{87}$ a teacher took (legitimate) photographs of school children. However, using a graphic manipulation package he would splice the head of the children onto pornographic pictures that he had downloaded, including images constituting child pornography. It is this form of manipulation that pseudo-photographs are often considered to involve. Apart from splicing photographs in this way, other examples would include taking an indecent photograph of an adult and then using a graphic manipulation package to thin out the pubic hair, reduce the breast size and thin hips etc. so that the resultant image looks like a child rather than an adult.

What is the justification for criminalising pseudo-photographs? In the situations discussed above there is no abuse of a child and, in some instances, there is no exploitation of a child. The exception is perhaps the type of activity that took place in $H$. Here, whilst there was no abuse of a child, it could legitimately be said that there has been exploitation of a child. A (real) child has had their image altered in a way to portray participation in sexual activity, when this did not happen. The resultant images are used for the purposes of sexual gratification (including where they are distributed) and this can legitimately be considered exploitative of that child. Where the child becomes aware of the image, then it is possible that they will suffer harm through not only the disgust that they will feel, but also the secondary victimisation discussed earlier. ${ }^{88}$

What of those situations where there was never a child involved? In other words, those types of pseudo-photographs where the image portrays an adult that has been altered to portray them as a child. For obvious reasons, it cannot be said that there has been any abuse or exploitation of $a$ child. The image only ever involved an adult so can it be justified to criminalise such images under child pornography laws?

Perhaps the strongest argument for doing so would be to rely on the dignity argument that has been discussed already. It was noted above that the dignity of an individual, which can be thought of as a derivative of the personal autonomy as an individual, is an issue that is separate from harm and therefore there is no reason why it could not apply even in situations where no direct harm has been caused. The protection of a person's autonomy must include how that person is presented, particularly in intimate ways. A person has the right to control who sees them in an intimate way. The morphing that takes place undermines this. Even where an adult has posed for a sexualised photograph, that is their choice at the time. It does not mean that they have surrendered any rights to how they are presented. A person may choose to pose in a particular way when they are adult, but they may not have wished to do so when they are younger than that age. Western society has particular views on child pornography and, indeed, teenage sexual behaviour (something picked up below) and therefore a subject may well believe that it would not be appropriate for it to look as though they had participated in child pornography when they did not. In this way, their dignity and autonomy are undermined.

\section{Virtual Child Pornography}

The most controversial type of material now commonly classed as child pornography is that known as 'virtual child pornography' although realistically it is wider than virtual images as it will include drawings, cartoons etc. Whilst some authors conflate virtual child pornography with morphed photographs, for the reasons set out above, that will not be the case here. For our purposes, virtual child pornography will be considered images that are produced without recourse to a photograph.

87 [2005] EWCA Crim 3037.

88 See $\mathrm{R} v \mathrm{H}$ [2005] EWCA Crim 3037 at [37]. 
International law adopts a mixed approach to virtual child pornography. One argument is that the OPSC includes virtual child pornography, because it refers to a depiction by 'any means', which must include virtual child pornography. However, the counter-argument is that the OPSC speaks of a child in the physical sense, meaning a real child, and therefore virtual child pornography may not be included. The Lanzarote Convention does specifically recognise virtual child pornography, but it permits member states to opt out of criminalising the production or possession of such images. ${ }^{89}$ The fact that there is an opt-out, perhaps demonstrates the controversy that exists.

England \& Wales adopted an unusual approach to criminalising virtual child pornography. For a start, it was arguably quite late at introducing a law. Whilst the Internet transformed the nature of child pornography, ${ }^{90}$ computers had been involved for much longer than the internet has become popular. The 1994 reforms, which recognised the increasing place of technology, were criticised for not tackling computer-generated images. ${ }^{91}$ Whilst there was recognition that a child may not be harmed in the production of such material, it was suggested that exposing children to such material could in itself be harmful and therefore justified criminalisation. ${ }^{92}$

The introduction in the USA of the Child Pornography Prevention Act 1996 led to considerable interest around the world in the establishment of laws to cover virtual child pornography. Whilst this Act ultimately did not survive constitutional review, ${ }^{93}$ it remained an important part of the desire of politicians to extend the laws of child pornography. Politicians across the world were pressurised into including virtual images and eventually in England \& Wales this happened with the introduction of the Coroners and Justice Act 2009.

The CJA 2009 did not amend the definition of the (existing) laws of child pornography, but rather introduced a new offence. This criminalises the possession of a prohibited image of a child. ${ }^{94}$ The first point to note, therefore, is that the offence is one of possession and it does not apply to the creation or distribution of an image. However, when one creates an image, a person will first be in possession of it and ordinarily a person who distributes an image will be in possession of it. ${ }^{95}$ Theoretically there is no need for the offence to apply to distribution since such matters would be covered by the Obscene Publications Act 1959.

The definition of a 'prohibited image of a child' raises a number of technical issues but for brevity these will be dealt with broadly. ${ }^{96}$ The first point to note is that, unlike photographs, a prohibited image must be obscene rather than indecent. ${ }^{97}$ Thus the threshold for intervention is higher than that for photographs. In fact, the requirement that it must be obscene is largely superfluous because the statute lists a series of sexual acts that must be depicted. ${ }^{98}$ These acts

89 Article 20(3).

90 Taylor and Quayle, n 15 above, discuss the transformation brought about by digital communication technologies.

91 Edwards, S. 'Suffer the little children - the Government's proposals on child pornography' (1995) 7 Child and Family Law Quarterly 49-58 at 55.

92 Ibid., at 57.

93 See Ashcroft v Free Speech Coalition 122 S.Ct. 1389 (2002).

94 Section 62(1), Coroners and Justice Act 2009.

95 However, it is certainly conceivable that this is not the case. So, for example, where an image is looked at on a screen in a cyber-café. D saves the image to the local desktop and then sends it to V. It is unlikely that D would be in possession of the image as he did not have custody and control of the PC ( R v Porter [2016[ 1 WLR 2633).

96 For an in-depth discussion of the provisions see Ost, S. 'Criminalising fabricated images of child pornography: a matter of harm or morality?’ (2010) 30 Legal Studies 230-256.

97 Section 62(2)(c), Coroners and Justice Act 2009.

98 Section 62(7), Coroners and Justice Act 2009. 
broadly cover sexual intercourse, oral sex, masturbation and sexual penetration. It is difficult to see how any of the acts (depicting a child) could not (legally) constitute an obscene image, but perhaps the wording is simply to reinforce the threshold.

The images must be pornographic, which means that they must 'reasonably be assumed to have been produced solely or principally for the purposes of sexual arousal'. ${ }^{99}$ Whilst this may seem obvious, it does perhaps act as a limit to the offence. Some cartoon images are probably produced for other reasons, including humour, and therefore they may not be within these provisions, even if they depict sexual activity.

The image must relate to 'a child' and this is taken to mean someone under the age of $18,{ }^{100}$ but it is clear the legislation is not restricted to real children. An image is to be treated as an image of a child' if-

(a) the impression conveyed by the image is that the person shown is a child; or

(b) the predominant impression conveyed is that the person is a child despite the fact that some of the physical characteristics are not those of a child. $^{101}$

This is then subject to a further refinement: 'references to an image of a child include references to an image of an imaginary child'. ${ }^{102}$

There are different ways of reading this, but at the very least it is clear that a child need not relate to a real child. Section 65(8) can only be read as meaning that a fictitious child, i.e. the creation of the imagination, would constitute 'a child' for these purposes. Section 65(6) means that it does not matter whether any of the characteristics of the image are not those of a child. The Act does not state that in these circumstances, they must be characteristics of an adult, and thus it would appear that the physical characteristics of imaginary creature would suffice so long as the predominant impression is that it is a child. Thus, cartoon characters could be within the meaning of the offence, as could presumably fairies or other creatures. So long as they looked to be child-like then they would seem to come within the scope of the offence.

The CJA 2009 offences were heralded in a consultation paper ${ }^{103}$ where the logic for extending the law into virtual child pornography was discussed. Interestingly, the government conceded 'we are not aware of any specific research carried out to ascertain whether there is a link between possession of these images and an increased risk of sexual offending against children ${ }^{104}$ yet they then went on to say that there was a feeling in the police and child protection charities that it did 'fuel' child abuse. This would seem a somewhat extraordinary way to conduct legislative drafting. To concede that there is no evidence to suggest harm but to sweep that aside and decide that people's "gut instinct" should be correct. Recently we have become used to terms such as 'alternative facts' and 'post-truth' but this demonstrates that the phenomenon is perhaps not as new as we believe.

99 Section 62(2)(a), Coroners and Justice Act 2009 when read in conjunction with s.62(3).

100 Section 65(5), Coroners and Justice Act 2009.

101 Sections 65(5)-(6), Coroners and Justice Act 2009.

102 Section 65(8), Coroners and Justice Act 2009.

103 Consultation Paper on Possession of Non-Photographic Visual Depictions of Child Sexual Abuse (2007, Home Office: London).

104 Ibid., at 6 . 
The consultation paper also put forward the belief that cartoon images could be used to groom children. ${ }^{105}$ The same argument was put forward by the US Federal government and it received short-thrift from the Supreme Court of the USA:

There are many things innocent in themselves...that might be used for immoral purposes, yet we would not expect these to be prohibited because they can be misused. ${ }^{106}$

Where there is concern that material could be used to groom children the correct response would be to criminalise that use not the material itself. Indeed, English law already criminalises forms of grooming ${ }^{107}$ and thus the mischief the Home Office complain of is subject to a criminal law intervention.

In the absence of any (provable) link to harm, on what basis can we justify criminalisation? Ost notes that the only potential alternative would be morality. ${ }^{108}$ Whilst morality can sometimes be considered to underpin criminalisation, it is noted by Ost that this usually requires a public element to it, and ordinarily morality could not justify criminalising simple possession. Indeed, this is one of the reasons why the Obscene Publications Act 1959 does not criminalise simple possession. Where the law has sought to extend a possession offence when it can realistically only be based on morality, concern has been raised. ${ }^{109}$

Perhaps it is indirect harm that could justify its criminalisation? It was noted above that Edwards was concerned that children could be harmed if they were exposed to such material. ${ }^{110}$ However, this does not justify an offence of simple possession where the defendant is likely to be an adult. Concern as to exposure requires an offence that tackles exposure, not possession. Levy suggests an alternative indirect harm. He argues that it represents the visualisation of sexual inequality. ${ }^{111}$ Thus he argues that virtual child pornography is intrinsically harmful to women as it reinforces stereotypes about sexual inequality. However, he then questions whether this would be sufficient by itself to justify its criminalisation. ${ }^{112}$ Presumably if it is taken to justify criminalising virtual child pornography, it would also justify the banning of all pornography. Whilst there have been some calls to do this, it is generally accepted that this is unlikely in a liberal democracy.

It would seem therefore that it is difficult to identify justifiable reasons for criminalising virtual child pornography. As noted above, the Home Office only half-heartedly attempted to justify its proposal to criminalise material and instead relied on the fact that the ordinary person would be disgusted by such material. That is undoubtedly true but that is why we have the Obscene Publications Act 1959. Technically the CJA 2009 offences will not affect the general population. It is an offence of simple possession and therefore it applies only to those who possess images, not to those who wish to distribute them. If we are to protect the public from disgusting images (and some would question whether that is a legitimate aim of the criminal law) then it must be

105 Ibid.

106 Ashcroft v Free Speech Coalition 122 S.Ct. 1389 (2002) at 1402.

107 See, most notably, sections 14 and 15, Sexual Offences Act 2003.

108 Ost, n 96 above, at 235-239.

109 See, for example, Ost, n 96 above and Attwood, F. and Smith, C. 'Extreme Concern: Regulating 'Dangerous Pictures' in the United Kingdom' (2010) 37 Journal of Law \& Society 171-188. For a contrasting opinion see Stone who criticised the offence of possession of indecent photographs although most would agree this was justified under the harm principle (Stone, R. 'Extending the Labyrinth: Part VII of the Criminal Justice and Public Order Act 1994' (1995) 58 MLR 389-394)).

110 Edwards, n 91 above, at 55.

111 Levy, N. 'Virtual child pornography: The eroticization of inequality' (2002) 4 Ethics and Information Technology 319-323 at 322.

112 Ibid., at 323. 
through tackling distribution and hosting, not simple possession. There is a belief that the OPA 1959 is not particularly effective ${ }^{113}$ but the solution to that is not to create a series of satellite offences, it is to reform the OPA 1959.

However, when dismissing the legitimacy of criminalising the possession of virtual child pornography, we should not operate on the basis that drawings etc. can never harm a child. Whilst it is true that a child need not be directly harmed to produce a drawing (in that it could be drawn from memory), that is not to say that a child is not harmed. An illuminating illustration of this is $\mathrm{R} v$ Milsom $^{114}$ which is a case that concerned an offender who pleaded guilty to various offences relating to child pornography but also historical child sexual abuse. Alongside the indecent photographs of children, just over 5,000 indecent drawings had been found. These depicted children being subjected to sadistic sexual abuse. It was noted that 'the name of KF featured in some of these drawings' ${ }^{115}$ who was the girl that was subjected to historic sexual abuse.

The historic sexual abuse does not appear to have been sadistic and the offender 'describes himself an artist' whose 'interest progressed to draw in particular. [His] work incorporated a formation of extremely violent and demeaning drawings of children. [He] claimed such work resulted from his imagination and said he became 'captivated' and 'obsessed' with this category of work'. ${ }^{116}$ In other words, his drawings are product of his imagination but, in his case, they dealt with real children. Can it be said that there is no harm involved here? Certainly there is no direct harm involved in their creation, but if the victim is aware of these images could there be harm? Quite apart from any emotional distress or harm that could be caused, we perhaps return to the issue discussed earlier about the inherent right to the dignity of an individual. These images inevitably impact upon that dignity of the individual.

It is notable that in Ashcroft v Free Speech Coalition, ${ }^{117}$ which remains perhaps the most important judicial examination of virtual child pornography, the Supreme Court and indeed the applicants themselves, accepted that where an image 'implicate the interests of real children' different issues arise. ${ }^{118}$ This must be correct and therefore whilst it is tempting to talk of 'virtual child pornography' in a broad way, it should be taken to mean those that do not involve a real child. Of course the question then arises, how does one know whether it is a real child? This is a good point. It has been noted already that identifying victims from photographs is a tenuous process, ${ }^{119}$ and doing so from drawings is likely to be even more difficult. The most obvious solution would be to place the onus on the possessor. A defence could be established that provides for the excusal of liability where it could be proved by the defendant ${ }^{120}$ that the image did not depict a real child. This is the strategy adopted by the Supreme Court of Canada in $\mathrm{R} v$ Sharpe $e^{121}$ and would exempt those who create and retain for their own use, fantasy images. It would also mean that people would be careful as to where they solicit the images. Whilst the US Supreme Court was sceptical as to the use of a reverse burden, ${ }^{122}$ they are more common within

113 See, for example, Travis, A. Bound and Gagged: A Secret History of Obscenity in Britain (2000, London: Profile Books).

114 [2011] EWCA Crim 2325.

115 Ibid., at [6].

116 Ibid., at [12] citing the pre-sentence report.

117 122 S.Ct. 1389 (2002).

118 Ibid., at 1397.

119 See n 20 above and associated main body text.

120 In other words, a reverse burden of proof would be established. There is precedent for this in respect of child pornography: see $\mathrm{R} v$ Collier [2005] 1 WLR 843.

1212001 SCC 2 at [76].

122 Ashcroft v Free Speech Coalition 122 S.Ct. 1389 (2002) at 1404. 
Europe and, in particular, England \& Wales. Its use in this context arguably strikes the right balance between the freedom of expression and protection of dignity.

\section{AdOLESCENT SEXTING}

The final issue of the definition that needs to be examined, albeit briefly, is the question as to who can be culpable for acts relating to child pornography. This is particularly relevant to the issue of so-called 'sexting'. This is the behaviour whereby a person transmits a sexualised photograph of themselves, normally naked, to another usually through MMS or social media. Whilst teenagers are certainly not the only people doing this, considerable attention has been placed on the fact that those under 18 do engage in this behaviour. ${ }^{123}$

According to the law in England \& Wales, a 'sexting' photograph of a person under the age of 18 constitutes an indecent photograph of a child. Thus both the sender and the recipient could breach the laws of child pornography. ${ }^{124}$ The absurdity of this for those aged 17 and 18 has already been noted. A 17-year-old can choose to have sexual intercourse with anyone, but if she chooses to send an image of herself topless to her boyfriend, then she commits a serious sexual offence.

It has been remarked that a difficulty with child pornography laws is that they are based on the concept of childhood innocence. ${ }^{125}$ Irrespective of what we know about teenage sexual experimentation, our laws are based on the premise that children are innocents in need of protection. When the age of 'a child' is 18 this can be problematic. Indeed, it returns us to the difficulty of the 'gaze of the paedophile' once again. It will be remembered that Adler, amongst others, believe that the laws of child pornography sexualise children because we view them through the eyes of a paedophile. It would seem likely that the same can be said of the laws relating to sexting.

Sexting has arguably become the moral panic of the $21^{\text {st }}$ century, with much controversy over what it is and why it happens. ${ }^{126}$ Research suggests that at least one reason is that teenagers see sexting as a way of expressing their sexual identity. ${ }^{127}$ Such expression is incompatible with the strict drafting of child pornography laws, where the emphasis is on children being innocents who are in need of protection. Indeed, it will be remembered from an earlier section, that this need to protect the innocent was one of the reasons why the age of 'a child' was raised to 18 . The behaviour known as sexting challenges this belief. The teenager becomes both the victim and the perpetrator. They are a victim because the law says they are in need of protection but they are also the perpetrator. By taking and distributing the image, the law states that they are the one who has interfered with childhood innocence and who is acting in an exploitative way.

The criminal justice system has not really understood how to resolve this dilemma. In some countries, adolescents engaging in consensual sexual sexting have been prosecuted, leading to considerable damage for the individual child. ${ }^{128}$ In England \& Wales the policing appears to be one of not deliberately seeking to arrest the child. That said, there are regular warnings by the

123 Hasinoff, A.A. 'Sexting as media production: Rethinking social media and sexuality' (2013) 15 New Media \& Society 449-465.

124 The former for taking an indecent photograph of a child and for distributing it (s.1, Protection of Children Act 1978). The latter for possession (s.160, Criminal Justice Act 1988) although if it was unsolicited, then this would be the case only if it were kept for an unreasonable length of time (see s.160(2)(c), Criminal Justice Act 1988).

125 Jenkins, $\mathrm{n} 17$ above.

126 Hasinoff, n 123 above.

127 Karaian, L. 'Lolita Speaks: Sexting, teenage girls and the law' (2012) 8 Crime, Media, Culture 57-73 at 67.

128 See, for example, Richard, RD and Calvert, C. 'When sex and cell phones collide: inside the prosecution of a teen sexting case' (2009) Hastings Communications and Entertainment Law Journal 1-40. 
police that engaging in this behaviour could lead to prosecution, and there have been isolated cases of adolescents being given formal cautions for sexting. ${ }^{129}$ This is despite the fact that it goes against the traditional approach of dealing with a protected class of victim. In $R v$ Tyrell $^{130}$ the then Lord Chief Justice recognised that a teenage girl between the ages of 13 and 16 could not be convicted of secondary participation to the crime of unlawful sexual intercourse with a girl under 16. The logic was that the legislation was designed to protect girls (including from themselves ${ }^{131}$ ) and therefore the teen could not be both victim and perpetrator. Admittedly, statute has now arguably reversed this, ${ }^{132}$ but it was a long-standing principle that had logical coherence. Child pornography laws unquestionably have a defined victim that they are designed to protect - the child - but the law is equally prepared for them to be the perpetrator, even when the only person that can be exploited is themselves.

The difficulty is that the law appears to have forgotten its purpose. It was noted that the law was introduced to protect children from abuse or exploitation. The current approach to sexting is premised on the approach that self-exploitation is as worthy of punishment (or protection) as the exploitation of others. The law does not do this in respect of other types of self-harm ${ }^{133}$ so why this form? Sexting contradicts the justification for child abuse laws. The primary justification is that which is based on the harm principle of the protection of dignity. If we look at harm first, where is the harm that the child suffers when it is they who take the picture? There is no direct harm as the activity portrayed will be consensual. There is no secondary harm either because this is premised on the basis that the subject of the photograph suffers psychological harm with the knowledge that the image is being used for sexual gratification. In sexting, the purpose - or one of the purposes - of the sending was sexual gratification so secondary harm is unlikely.

What of dignity? It will be remembered that this is grounded in individual autonomy. Sexting does not infringe autonomy. If anything, the current laws of child pornography infringe the autonomy of the adolescent by precluding the child expressing its sexual identity if it so wishes. Where the child is over the age of consent then it is difficult to justify this approach. Even where the child is below the age of consent, it is difficult to see how criminalising the sending of a picture of oneself protects autonomy.

Of course, it must be conceded that sexting is not always consensual. There is evidence that some - typically girls - are pressured into sending photographs. ${ }^{134}$ Similarly, there is no guarantee that once an image has been sent, the recipient will not forward it to others without the subject's consent. However, it would be strange to use that as a basis for justifying the criminalisation of the victim. In the first situation the law should treat this as a non-consensual sexual act in the same way as though it were unwanted sexual activity. Where a 14-year-old girl is pressurised into allowing her boyfriend to feel her breasts, nobody would suggest criminalising the girl, so why is there that risk when she takes a photograph of her breasts? In the second example - further distribution - the law can obviously deal with this. The recipient who further disseminates the

129 See, for example, 'Teenage girl given police caution for 'sexting' explicit selfie to boyfriend' (2014) The Telegraph, 22 July, News.

130 [1894] 1 QB 710.

131 See Lord Coleridge at [1894] 1 QB 710 at 712.

132 Section 13, Sexual Offences Act 2003 establishes a criminal offence of sexual offences committed by children. Whilst it does not technically overrule Tyrell, a girl who sought to procure her own sexual intercourse would undoubtedly commit an offence under s.9, which would then be prosecutable under s.13.

133 See Gillespie, A.A. Cybercrime: Key Issues and Debates (2016, London: Routledge) pp.192-201.

134 Walker, S. and Sanci, L. 'Sexting: Young Women's and Men's Views on Its Nature and Origins' (2013) 52 Journal of Adolescent Health 697-701 but see Lee, M. and Crofts, T. 'Gender, Pressure, Coercion and Pleasure: Untangling Motivations for Sexting Between Young People' (2015) 55 British Journal of Criminology 454-473 who suggest this is a minor aspect of sexting. 
image will have distributed an indecent photograph of a child. In the circumstances presented, (s)he will have certainly interfered with the autonomy of the subject and potentially caused (secondary) harm. Thus a prosecution would be deserved, but once again, that does not justify the risk that the subject herself could be prosecuted.

Sexting by adolescents is not harmless and the preceding paragraphs should not be taken as a condonation of the behaviour by those under the age of consent. There are permanent consequences and these do need to be understood. But these risks do not justify criminalising what is, in essence, self-harm. More appropriate responses would be educational or welfarebased. To that extent, the law must change.

\section{CONCLUSION}

Child pornography laws are both controversial and non-controversial, a somewhat remarkable feat. The vast majority of material classified as child pornography deserves to be criminalised. Where a child is being photographed being abused or exploited, then few would question the need to prohibit this material. Children deserve protection and child pornography not only records the abuse that they have suffered, but prolongs it by ensuring that the abuse stays alive through not only the photographs but also through the knowledge that people gain sexual gratification from looking at the abuse. As a contribution to protecting children, therefore, the laws relating to child pornography are both welcome and justified.

The difficulty is that, as has been seen in this paper, the law has begun to stray away from the desire to protect children. There are areas where it no longer serves to protect children or individuals, and instead adopts a paternalistic stance that could be viewed as infringing the rights of an individual to free expression or sexual autonomy. This creep is a relatively new phenomenon and is to be regretted. The difficulty is that many of the advances have been made without considering the full realities of what was being proposed. Because the vast majority of child pornography is repugnant and harmful, it is easy to wave through amendments, believing that they must be appropriate. Few politicians are going to stand up and speak out against child pornography laws, and thus laws are passed with little oversight, something that is not always wise.

The first area where the law has arguably moved away from protecting children, however, is not a fault of statute (or not directly) but rather a fault of the common law. The Protection of Children Act 1978 did not define 'indecent' and this has meant that its interpretation arguably includes material that would not always seem to be classed as child pornography. In fairness, most incidents are resolved in such a way that there is not a prosecution (including the position in respect of both Julia Sommerville and the Nan Golding photographs), but that does not excuse the test. A criminal justice response is unpleasant. Being arrested and interviewed for child pornography offences is not pleasant and could have social repercussions. The test should be altered so that innocuous pictures do not fall within the test of indecency. The purely objective test that is currently used must be set aside and replaced with a more nuanced test, such as that adopted in s.78, Sexual Offences Act 2003. Thankfully the English courts have not gone so far as the American courts and criminalised photographs in swimwear but, in fact, there is arguably nothing within the current test that would prevent that from happening. Clarity should be brought to the test so that all, investigators and the public alike, are aware of where the line is being drawn. 
Some innovations have been perhaps criticised unfairly. Pseudo-photographs have been the subject of some criticism ${ }^{135}$ but it has been seen that in many instances this is not fair. Whilst it may not be the case that pseudo-photographs show the direct harm of a child, it is not possible to say that pseudo-photographs are not harmful. It will be remembered that some forms of pseudo-photographs depict real children in scenes that suggest they are engaging in sexual activity or are being subject to child sexual abuse. This is a harm in itself. Not only is it misrepresenting an individual in a way that is inappropriate, it can lead to emotional harm where a child discovers that the images exist. More than this, secondary harm can be caused by the realisation that the pictures are being circulated and used for the purposes of sexual gratification. The permanence of images means that victims are afraid of being recognised and of being judged. Thus harm is caused and their criminalisation can be justified.

What of those pseudo-photographs that do not involve a child but an adult? It will be remembered that harm can still be attributed to these. We all have sexual autonomy and where a real person is being portrayed in child pornography, their sexual autonomy is being interfered with when they are presented in ways that they do not agree to or which are unrepresentative of their behaviour. When they are being portrayed as engaging in sexual activity as an adolescent or child, there is a danger that they will be judged in an inappropriate way. This may be them being viewed as voluntarily engaging in inappropriate behaviour, or it could be them (wrongly) being identified as a victim of abuse. Either way, the sexual misrepresentation of them as a youth is not appropriate.

Virtual child pornography however raises very different issues. If we set aside those situations that depict a real child, since they raise the same issues as identified in respect of pseudophotographs, and concentrate on fictitious material, it becomes very difficult to justify the criminalisation of the possession of such material. The government, in its consultation paper, recognised that there was no evidence that there was any link between the possession of virtual child pornography and the harm to children. ${ }^{136}$ It nonetheless went on to criminalise the possession of such material. Criminalising the private possession of material can only be justified where there is a real risk of harm being caused to another and this simply is not the case here. The position becomes even more untenable when it is realised that the legislation extends not only to realistic drawings of children, but also to cartoons and drawings, including of fantasy creatures. The Coroners and Justice Act 2009 is drafted so widely that if a pixie is viewed as childlike then the visual depiction of it engaging sexually is criminal. The protection of pixies is far removed from the protection of children and the legislation can only be viewed as an interference of the expression of an individual.

The shift away from the protection of children is also evident from the raising of the age of 'a child' to 18. Without altering the rest of the legislation, this simple act meant that in some cases, photographs ceased to portray an illegal act and started to criminalise the depiction of lawful sexual activity. This was done because there was a belief that adolescents did not understand the implications of the internet and the consequences of their behaviour. No research was put forward to support this, and it is questionable that an 18-year-old understands the consequences anymore than a 17-year-old does. More than this, however, it adopts a paternalistic approach whereby 16 and 17-year-olds are trusted to make decisions relating to contraception, abortion and sexually transmitted diseases but not over the portrayal of their bodies.

135 Nair, A. 'Real porn and pseudo porn: The regulatory road' (2010) 24 International Review of Law, Computers \& Technology 233-232.

136 n 103 above. 
The most damning shift away from the protection of children is evident in the law's treatment of sexting. The law allows for the criminalisation of the victim, something that is simply inappropriate. Sexting is undoubtedly problematic in a number of ways, but that does not justify invoking the criminal law against the child itself. If the laws relating to child pornography are designed to protect children from abuse or exploitation, how can that be achieved by punishing the very people that they seek to protect? The consequences of a conviction or formal caution are significant and they should be imposed only where appropriate.

To conclude, child pornography is, in at least some respects, an example of dangerous speech. Whilst in many instances the laws are appropriate and applied in ways that undoubtedly protect children, in other ways they have the potential to criminalise those who are not harming children and who are engaged with material that could be considered expressive. The shift away from the protection of children is to be regretted and there is a need to reset the laws so that the vulnerable child is once more at the heart of the laws. 